\title{
TATAI ZOLTÁN: A TERÜLETFEJLESZTÉS EGYETEMI OKTATÁSÁRÓL
}

\author{
(Területfejlesztö Öregdiákok Közössége, Budapest, 2005, \\ 178 o., Nyomdakész Kft., Veszprém) \\ TÖRÖK FERENC
}

A karcsú kötet a Budapest XIV., Ajtósi-Dürer sor 19-21. szám alatti ELTE épületcsoport konferenciatermében, 2005. december 2-án tartott összejövetel anyagát tartalmazza dr. Tatai Zoltán nyugalmazott egyetemi docens szerkesztésében. A borítón látható 1895-ben elkészült patinás épület 1948-ig a Sacré-Coeur Apácarend oktatási tevékenységének szolgálatában állott. 1950-töl a Pártföiskola hasznosította, melynek 1968-tól már egyetemi státusú intézményében 1975-1990 között a terïletfejlesztési szakon is lehetett diplomát szerezni. Tizenöt év alatt ez 180 hallgatónak sikerült.

A konferencia programját vezetỏ Romány $P a ́ l$ nyugalmazott rektor bevezetőjében hajdani tanárának dr. Czettler Jenö akadémikusnak a szavait idézte (1939):

„Az új gazdasági rendet máról holnapra, sem az egyéni tudás és akarat, sem az állami beavatkozás nem képes kikényszeríteni, mert mindez az erö csak azt formálhatja és fejlesztheti, ami anyagi és szellemi javakban rendelkezésre áll."

A területfejlesztési tudomány oktatásának hazai megalapozása Markos György professzor nevéhez köthető aki az (MKKE) 1949-1951 között beiskolázott („C” szakos) hallgatóságnak adott modern elméleti és gyakorlati képzést. Az itt végzettek közül ma is elismert szaktekintélyek: Antal Zoltán, Cravero Róbert, Enyedi György, Illés Iván, Lackó László, Stark Antal, Tatai Zoltán, Wirth Gyula... és sokan mások. 1975-1990 között Tatai Zoltán a Markos-iskola szellemében, annak továbbfejlesztett, tudatosabb formájában szervezte, irányította a Politikai Főiskolán a területfejlesztési szakemberek képzését.

A könyv elsö fejezetében foglalkozik a szerző a szak elökészítésével, az oktatási program kialakításával, a módszerekkel. Részletesen ír az elméleti oktatás próbájának tekintett tanulmányutakról és azok tapasztalatairól. Bemutatja a szakma élvonalát képviselö előadókat, elemzi a hallgatók összetételét. A fejezet mellékletében eredeti dokumentumok alapján áttekinthető egy-egy év tanterve, az államvizsgakérdések, a tananyag, szakdolgozat és doktori értekezés címek.

A könyv második fejezete egykori hallgatók területfejlesztési szakról szóló hangulatos írásait, a munkakörükben történó hasznosítás tapasztalatait és néhány mai civil kezdeményezésű vita szakmai szempontokkal történő összevetését tartalmazza.

A harmadik fejezetben Antal Zoltán, Bartke István, Perczel György és Nemes Nagy József aktuális témát feldolgozó, a konferencián elhangzott felszólalásai olvashatók. Példaként az utolsóként említett elöadó (az ELTE egyetemi tanára) geográfus területfejlesztókról szóló ismertetése emelhető ki. 
A függelék érdekessége egy válogatás az 1958-1987 között született országgyülési, kormány és miniszteri dokumentumokból, amelyek a terület-és településfejlesztés tárgykörében íródtak, és az oktatás során felhasználásra kerültek.

Összegezve: Biztosan állítható, hogy a könyv az egykori hallgatók és oktatók számára pótolhatatlan emlékkötet. Valószínüsíthető, hogy a ma terüiletfejlesztést tanulók, oktatók és gyakorlók is haszonnal forgathatják már csak az elért eredmények megismerése, a hibákból való okulás céljából is. Hiszen a sikeres folytatás és újrakezdés tétje sem mindennapi: az országnak, a régiós Európa együttmüködésébe történő minél hatékonyabb bekapcsolódása.

Beszerezhetö Tatai Zoltán 1032 Budapest. Kiscelli u. 16. V/34. (korlátozott példányban) 